\title{
Cold Atmospheric Plasma (CAP) and CAP-Stimulated Cell Culture Media Suppress Ovarian Cancer Cell Growth - A Putative Treatment Option in Ovarian Cancer Therapy
}

\author{
DOMINIQUE KOENSGEN ${ }^{1}$, ILMA BESIC ${ }^{1}$, DENIS GÜMBEL ${ }^{2}$, ANNE KAUL ${ }^{1}$, \\ MARTIN WEISS ${ }^{3}$, KAROLINE DIESING $^{1}$, AXEL KRAMER ${ }^{4}$, \\ SANDER BEKESCHUS ${ }^{5}$, ALEXANDER MUSTEA ${ }^{1 *}$ and MATTHIAS B. STOPE ${ }^{6 *}$ \\ Departments of ${ }^{1}$ Gynecology and Obstetrics, ${ }^{2}$ Trauma and Orthopaedic Surgery, \\ ${ }^{4}$ Hygiene and Environmental Medicine and 6Urology, University Medicine Greifswald, Greifswald, Germany; \\ ${ }^{3}$ Department of Obstetrics and Gynecology, University Hospital Tuebingen, Tuebingen, Germany; \\ ${ }^{5}$ ZIK Plasmatis, Leibniz-Institute for Plasma Science and Technology (INP Greifswald), Greifswald, Germany
}

\begin{abstract}
Background/Aim: Ovarian cancer (OC) is a gynecologic tumor with poor prognosis. Despite radical cytoreductive surgery and platinum-based adjuvant systemic treatment, OC will relapse in the majority of the cases. Thus, cold atmospheric plasma (CAP), a highly reactive physical state bearing diverse biological activities being suited for anticancer therapy, may be a promising option in $O C$ therapy. Materials and Methods: OC cell lines were exposed either directly to the CAP or to cell culture medium previously exposed to CAP. Cell proliferation and cell motility was measured. Results: The data demonstrated, that even a single application of a short-term CAP treatment led to an attenuation of $O C$ cell growth and motility. Moreover, incubation with CAP-treated cell culture medium gave similar effects. Results were consistent in four OC cell lines. Conclusion: In summary, the CAP application in oncological surgery leads to strong anti-proliferative effects and opens up novel opportunities for the OC treatment.
\end{abstract}

Although ovarian cancer (OC) ranks eighth among the most common female malignancies, it is the fifth cause of death from cancer in women (1). This discrepancy is largely attributed to the fact that the majority of patients present with

*These Authors contributed equally to this work.

Correspondence to: Matthias Stope, Department of Urology, University Medicine Greifswald, Ferdinand-Sauerbruch-Strasse, 17475 Greifswald, Germany. Tel: +49 38348680436, Fax: +49 38348680435, e-mail: matthias.stope@uni-greifswald.de

Key Words: Ovarian cancer, novel therapy, cold atmospheric plasma. advanced disease at the time of diagnosis. OC entities are composed of several sub-types with widely differing clinicopathological, genetic, and molecular features (2). The pronounced morphologic and molecular heterogeneity combined with non-specific symptoms in already advanced stages hinders striking OC therapy strategies in most of the cases.

OC therapy consists of an upfront surgery aiming at macroscopic complete resection and combined platinumbased chemotherapy with carboplatin and paclitaxel and, most recently, bevacizumab (3). Despite radical cytoreductive surgery and platinum-based adjuvant systemic treatment, OC will relapse in the majority of cases.

Based on studies on other cancer entities including prostate and breast cancer (4-6) as well as different OC cell lines in vitro and in vivo (7-11), the application of cold atmospheric plasma (CAP) may become a promising option for OC therapy, particularly for intraoperative application adjacent to critical sites. CAP is defined as a highly reactive partially ionized physical state containing diverse biologically reactive factors including reactive oxygen and nitrogen species (ROS, RNS). This broad spectrum of bioactive agents in combination with charged particles, electric field and shock waves is not achievable with any other therapeutic method. Biological efficacy of CAP is primarily characterized by cell typespecific cell growth modulation, promotion of wound healing and scar formation, activity against microorganisms and viruses, and the modulation of inflammation, leukocyte behaviour, and apoptosis $(5,6,12-19)$. Notably, due to a weaker antioxidant capacity, CAP selectively attacks cancer cells and induces immunogenic cell death with potentially improve the imunnogenicity of cancer cells $(20,21)$.

In the presented study, we performed proof-of-concept experiments for the application of CAP in OC treatment in vitro. 


\section{Materials and Methods}

Cell culture and CAP treatment. The OC cell lines OVCAR-3 (Cell Lines Service, Eppelheim, Germany), SKOV-3 (Cell Lines Service, Eppelheim, Germany), TOV-21G (American Type Culture Collection, Manassas, VA, USA), and TOV-112D (American Type Culture Collection, Manassas, VA, USA) were propagated in RPMI 1640 medium (Biochrom, Berlin, Germany) supplemented with $10 \%$ fetal bovine serum (Biochrom, Berlin, Germany), $0.125 \%$ gentamicin (Ratiopharm, Ulm, Germany), and $0.1 \%$ insulin (Novo Nordisk, Mainz, Germany) (OVCAR-3), DMEM/F12 (Life Technologies, Darmstadt, Germany) containing 5\% fetal bovine serum (Biochrom, Berlin, Germany), and $0.125 \%$ gentamicin (Ratiopharm, Ulm, Germany) (SKOV-3), and MCDB105 (tebu-Bio, Offenbach, Germany)/medium 199 (Biochrom, Berlin, Germany) mixture containing $15 \%$ fetal bovine serum (Biochrom, Berlin, Germany), and $0.125 \%$ gentamicin (Ratiopharm, Ulm, Germany) (TOV-21G, TOV-112G), respectively. Cells were passaged twice a week in a humidified atmosphere at $37^{\circ} \mathrm{C}$ and $5 \% \mathrm{CO}_{2}$.

For CAP treatment, $3.0 \times 10^{4}$ cells in $500 \mu \mathrm{l}$ cell culture medium were treated with CAP for indicated times with the atmospheric pressure argon plasma jet kINPen MED (neoplas tools, Greifswald, Germany) at three standard liters per minute, $65 \mathrm{~V}$ supply voltage and $1.1 \mathrm{MHz}$ frequency. After CAP exposure, cells were incubated for $120 \mathrm{~h}$. Control cells were treated with argon gas. Alternatively, cell culture medium was exposed to CAP and subsequently diluted with cell suspension 1:2.

Proliferation assay. Cellular growth was assessed by use of a CASY Cell Counter and Analyzer Model TT (Roche Applied Science, Mannheim, Germany). Cells were diluted in CASYton solution (1:100, Roche Applied Science) and $400 \mu$ of cell suspension were measured in triplicates using a capillary of $150 \mu \mathrm{m}$ in diameter and gate settings of $9.00 \mu \mathrm{m} / 15.75 \mu \mathrm{m}$ (OVCAR-3), $7.00 \mu \mathrm{m} / 15.15 \mu \mathrm{m}$ (SK-OV-3), $5.25 \mu \mathrm{m} / 10.15 \mu \mathrm{m}$ (TOV-21G), and $6.15 \mu \mathrm{m} / 11.00 \mu \mathrm{m}$ (TOV-112D).

Cell motility assay. A total of $1.0 \times 10^{5}$ cells per well were CAP treated for $15 \mathrm{~s}$ (OVCAR-3, SKOV-3, TOV-21G), and $30 \mathrm{~s}$ (TOV$112 \mathrm{G}$ ), seeded in a 24-well cell culture plate and incubated at $37^{\circ} \mathrm{C}$ and $5 \% \mathrm{CO}_{2}$ for $24 \mathrm{~h}$. Subsequently, cell layers were scratched with a $200-\mu \mathrm{l}$ pipette tip and imaged for $48 \mathrm{~h}$ in a life cell imaging setup at $37^{\circ} \mathrm{C}$ and $5 \% \mathrm{CO}_{2}$. Light microscopical analysis in an Axio Observer Z1 microscope (Carl Zeiss, Oberkochen, Germany) was performed every $6 \mathrm{~h}$ and cell translocation into the cell-free scratch was analyzed using ZEN pro 2012 software (Carl Zeiss, Oberkochen, Germany). Cell motility was expressed as a relative decrease of the cell-free space (cell-free growth area) of the scratch compared to $\mathrm{t}=0$.

Statistics. Data are given as the mean \pm standard deviation (SD). Statistical comparison was performed using the unpaired Student's $t$-test. $p \leq 0.05, p \leq 0.01$, and $p \leq 0.001$ were considered as significant.

\section{Results}

CAP exposure leads to anti-proliferative effects on OC cells. The anti-proliferative efficacy of CAP was dependent on treatment duration as well as on the used OC cell line. Generally, growth inhibition after CAP treatment increased with the length of the treatment (Figure 1). TOV-21G cells, however, appeared more sensitive to CAP because their proliferation was significantly inhibited after $10 \mathrm{~s}$ and $15 \mathrm{~s}$, respectively (Figure 1G-I). In contrast to TOV-21G cells, TOV-112G cells demonstrated reduced sensitivity to CAP, resulting in prolonged treatment exposure of $10 \mathrm{~s}, 20 \mathrm{~s}$, and $30 \mathrm{~s}$ (Figure 1J-L) for similar effects compared to the other OC cell lines.

The anti-proliferative efficacy of CAP treatment depends on the cell culture medium composition. To investigate CAP's indirect impact on OC cells via CAP activated biofluids, cell culture medium was treated as mentioned above followed by an incubation of untreated OC cells with treated medium for $120 \mathrm{~h}$. Neither medium A (DMEM F12; Figures 2 A to C) nor medium B (MCDB105/Medium 199; Figures $2 \mathrm{D}$ to $\mathrm{F}$ ) interfered with OC cells after CAP activation (Figure 2). The volume of treated medium was not important in mediating CAP-dependent effects. Performing these experiments using $1000 \mu \mathrm{l}$ of CAP treated medium A and medium B, respectively, gave no growth deceleration (data not shown). Only medium $\mathrm{C}$ (RPMI 1640; Figure $2 \mathrm{G}$ to I) conveyed CAP effects on OC cells and inhibited untreated OVCAR-3 cells after CAP treatment of $200 \mu \mathrm{l}$ of medium. Again, application of $1000 \mu \mathrm{l}$ of CAP treated medium $\mathrm{C}$ demonstrated very similar effects on OC cell growth (Figure 2J-L).

CAP exposure inhibits the cellular motility of OC cells. Beside cellular growth, the complex network of cellular motility, invasion, and metastasis is one of the primary hallmarks of cancer. Performing scratch assays with CAPtreated OC cells, anti-metastatic efficacy of CAP has been demonstrated. Specifically, SKOV-3 (Figure 3B) and TOV$21 \mathrm{G}$ (Figure 3C) cells showed an attenuated but nonsignificant influx into scratched areas. In contrast, CAP treatment of OVCAR-3 (Figure 3A) and TOV-112G (Figure 3D) cells significantly inhibited the motility of both cell lines over a period of $48 \mathrm{~h}$.

\section{Discussion}

First, in 2012, Iseki et al. have suggested anti-proliferative CAP effects on OC cell lines SKOV-3 and HRA (22). The authors demonstrated a reduced cell metabolic activity $72 \mathrm{~h}$ after CAP exposure in both cell lines, pointing to a declined cellular viability. Omran et al. confirmed with a transporting and flexible plasma jet the eradication of OC cells in vitro (11) and Utsimi et al. demonstrated anticancer effects of CAP-activated medium on chemoresistant $\mathrm{OC}$ cells in vitro and in vivo $(8,9)$. Notably, the more aggressive population of OC cells derived from patients ascites was more sensitive to CAP treatment than the less aggressive type (10). 

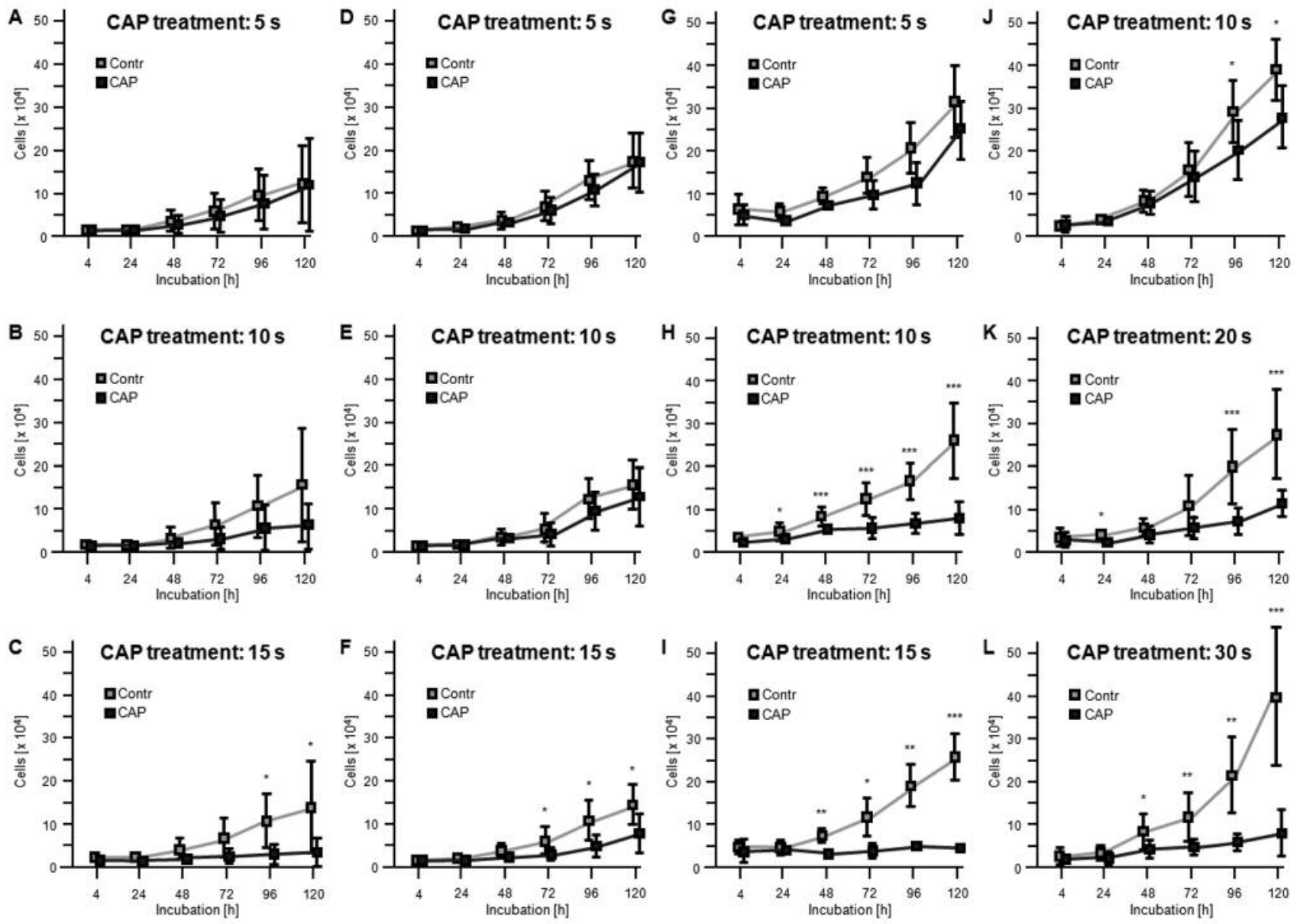

Figure 1. Anti-proliferation after CAP treatment of OC cells. OC cells OVCAR-3 (A-C), SKOV-3 (D-F), TOV-21G (G-I), and TOV-112G (J-L) were exposed to CAP (CAP) for $5 \mathrm{~s}, 10 \mathrm{~s}$, and $15 \mathrm{~s}(\mathrm{OVCAR}-3, \mathrm{SKOV}-3, \mathrm{TOV}-21 \mathrm{G})$ and $10 \mathrm{~s}, 20 \mathrm{~s}$, and $30 \mathrm{~s}$ (TOV-112G), respectively, and cell counts were performed at the indicated time points. Control cells (Contr) were treated similarly with argon carrier gas. Data are given as the mean $\pm S D$

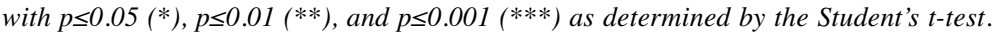

In our study, we performed CAP exposure experiments utilizing the OC cell culture model consisting of SKOV-3, OVCAR-3, TOV-21G, and TOV-112G cells, which represents a well-characterized established in vitro model particularly in the field of $\mathrm{OC}$ treatment resistance and cancer progression research (23-26). Our data demonstrated remarkable anticancer effects over a period of $120 \mathrm{~h}$ by cell counting, indicating direct cell number alterations. As expected, the anti-proliferative efficacy of CAP was dependent on the individual OC cell type and the exposure time, reflecting $\mathrm{OC}$ heterogeneity and dose-response effects. A decrease in scratch re-population was observed for all four OC cell lines. Moreover, CAP effects could be indirectly transferred to cells by treatment of the cell culture medium. This effect did not interfere with the liquid volume which has been treated with CAP, but with the chemical composition of the medium. Even though the protein composition in cell culture medium remains unchanged after CAP exposure (27), however, several biologically effective species are generated, e.g. superoxide $\left(\mathrm{O}_{2}^{-}\right)$, singlet oxygen $\left({ }^{1} \mathrm{O}_{2}\right)$, hydrogen peroxide $\left(\mathrm{H}_{2} \mathrm{O}_{2}\right)$, and ozone $\left(\mathrm{O}_{3}\right)$ (28). Consequently, physical parameters of the medium which determine cellular viability, e.g. $\mathrm{pH}$, electrical conductivity, and UV transmittivity, may be affected by CAP treatment according to the composition of the cell culture medium. As a result, reactive species together with critical changes in liquid physics might enable to mediate CAP's efficiency even indirectly $(27,29,30)$. Due to the high content of amino acids, vitamins, and other organic compounds and due to the higher buffer capacity of DMEM compared to RPMI (31), DMEM medium appears more appropriate to neutralize CAP effects in liquids. In the clinical context, coagulating 

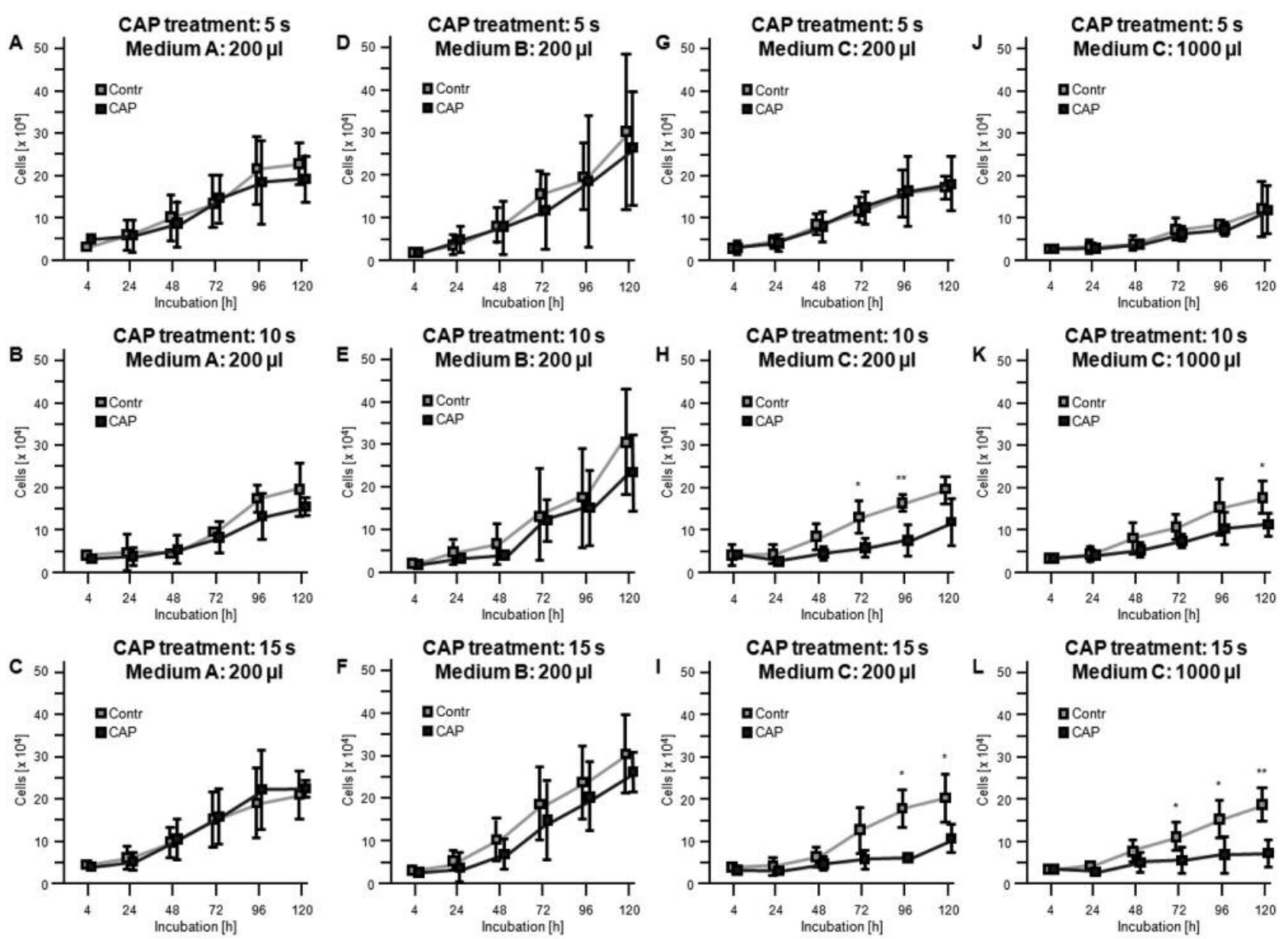

Figure 2. Indirect CAP effects of CAP-treated cell culture media on untreated OC cells. Untreated OC cells SKOV-3 (A-C), TOV-21G (D-F), and OVCAR-3 (G-L) were incubated with medium A (DMEM/F12; A-C), medium B (MCDB105/Medium 199 mixture; D-F), and medium C (RPMI 1640; $G-L)$, respectively, which were exposed to CAP for $5 \mathrm{~s}, 10 \mathrm{~s}$, and $15 \mathrm{~s}$, respectively, and cell counts were performed over a period of $120 \mathrm{~h}$ at the indicated time points. In control samples (Contr), media were treated similarly with argon carrier gas. Incubation experiments were performed using $200 \mu \mathrm{l}(\mathrm{A}-\mathrm{I})$ and $1000 \mu \mathrm{l}(\mathrm{J}-\mathrm{L})$ of CAP treated media. Data are given as the mean $\pm S D$ with $p \leq 0.05(*)$, and $p \leq 0.01$ (**) as determined by Student's t-test.
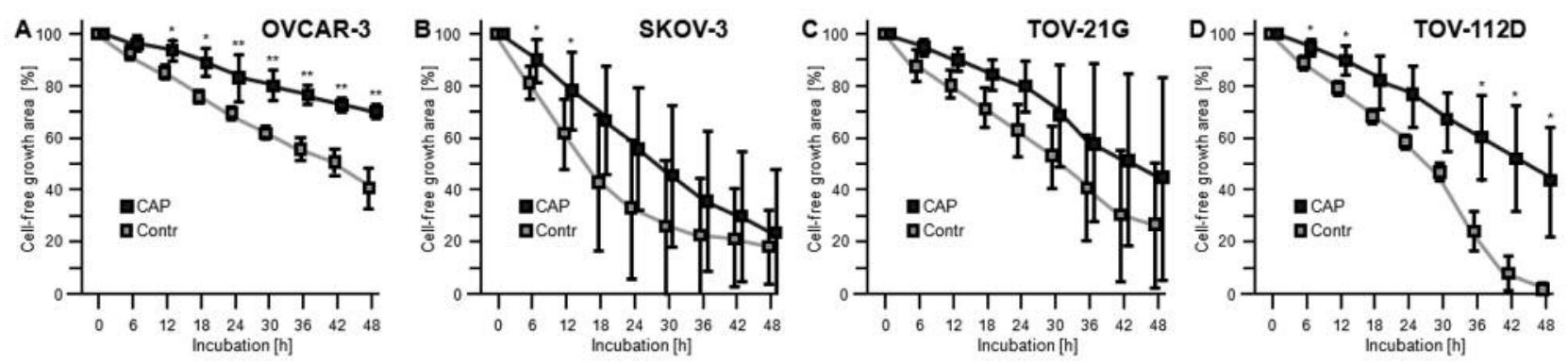

Figure 3. Cell motility inhibitory effects of CAP on OC cells. OVCAR-3 (A), SKOV-3 (B), TOV-21G (C), and TOV-112G (D) cells were exposed to CAP for $15 \mathrm{~s}$ (OVCAR-3, SKOV-3, TOV-21G), and $30 \mathrm{~s}$ (TOV-112G), respectively, and propagated in 24-well cell culture plates for 24 h. Subsequently, monolayers were scratched and imaged for up to $48 \mathrm{~h}$ in a life cell imaging setup. Light microscopical analysis was performed every $6 \mathrm{~h}$ and cell translocation into the cell-free scratch was expressed as relativ decrease of the cell-free space of the scratch compared to t=0. Control cells (Contr) were treated similarly with argon carrier gas. Data are given as the mean $\pm S D$ with $p \leq 0.05(*)$, and $p \leq 0.01$ (**) as determined by the Student's t-test. 
effects of CAP will also play an important role. CAP treatment efficiently achieves blood coagulation without thermal effects (32) and, thus, intraoperative CAP applications would primarily be restricted to the site of surgery without subsequent systemic effects. Moreover, previous studies demonstrated the kINPen Med CAP being genotoxically safe $(33,34)$.

First hints were generated to the mode of action of CAP suppressing ovarian and breast cancer cell growth. Macranthoside B, a saponin compound with anticancer efficacy, blocks proliferation and induces apoptosis of OC cells via reactive oxygen species accumulation (35). These findings, when considered together with the study of Yan $e t$ al. demonstrating that CAP treatment generated reactive oxygen species at the micromolar level (36), may provide a new prospective to understand the interaction between CAP and cancer cells.

In summary, the CAP application in oncological surgery opens up novel opportunities for OC therapy. The study presented here demonstrated that even a single application of a short-term CAP treatment leads to attenuation of cell growth as well as to inhibition of the metastatic capability of OC cells. The study, however, is limited by its restriction to an in vitro cell culture model. Consequently, semi-in vivo tests, e.g. the hen's egg test-chorio allantoic membrane (HET-CAM) and animal models, are needed to confirm these results.

\section{References}

1 Siegel RL, Miller KD and Jemal A: Cancer statistics, 2015. CA: A Cancer Journal for Clinicians 65: 5-29, 2015.

2 Reid BM, Permuth JB and Sellers TA: Epidemiology of ovarian cancer: a review. Cancer Biol Med 14: 9-32, 2017.

3 Stuart GCE, Kitchener H, Bacon M, duBois A, Friedlander M, Ledermann J, Marth C, Thigpen T and Trimble E: 2010 Gynecologic Cancer InterGroup (GCIG) consensus statement on clinical trials in ovarian cancer: report from the Fourth Ovarian Cancer Consensus Conference. Int J Gynecol Cancer 21: 750755, 2011.

4 Mirpour S, Piroozmand S, Soleimani N, Jalali Faharani N, Ghomi H, Fotovat Eskandari H, Sharifi AM, Mirpour S, Eftekhari $\mathrm{M}$ and Nikkhah M: Utilizing the micron sized nonthermal atmospheric pressure plasma inside the animal body for the tumor treatment application. Sci Rep 6: 29048, 2016.

5 Weiss M, Gumbel D, Hanschmann E-M, Mandelkow R, Gelbrich N, Zimmermann U, Walther R, Ekkernkamp A, Sckell A, Kramer A, Burchardt M, Lillig CH and Stope MB: Cold atmospheric plasma treatment induces anti-proliferative effects in prostate cancer cells by redox and apoptotic signaling pathways. PLoS ONE 10: e0130350, 2015.

6 Weiss M, Gümbel D, Gelbrich N, Brandenburg LO, Mandelkow R, Zimmermann U, Ziegler P, Burchardt M and Stope MB: Inhibition of cell growth of the prostate cancer cell model LNCaP by cold atmosperic plasma. In Vivo 29: 611-616, 2015.

7 Iseki S, Nakamura K, Hayashi M, Tanaka H, Kondo H, Kajiyama H, Kano H, Kikkawa F and Hori M: Selective killing of ovarian cancer cells through induction of apoptosis by nonequilibrium atmospheric pressure plasma. Appl Phys Lett 100: 113702, 2012.

8 Utsumi F, Kajiyama H, Nakamura K, Tanaka H, Hori M and Kikkawa F: Selective cytotoxicity of indirect nonequilibrium atmospheric pressure plasma against ovarian clear-cell carcinoma. Springerplus 3: 398, 2014.

9 Utsumi F, Kajiyama H, Nakamura K, Tanaka H, Mizuno M, Ishikawa K, Kondo H, Kano H, Hori M and Kikkawa F: Effect of indirect nonequilibrium atmospheric pressure plasma on antiproliferative activity against chronic chemo-resistant ovarian cancer cells in vitro and in vivo. PLoS ONE 8: e81576, 2013.

10 Trink B, Keidar M, Canady J, Shamai Y and Tzukerman M: The effect of cold atmospheric plasma treatment on cancer stem cells. Plasma Med 5: 17-26, 2015.

11 Omran AV, Baitukha A, Fakhouri H, Arefi-Khonsari F, Mirshahi $\mathrm{M}$ and Sohbatzadeh F: Ovarian cancer cells treatment using a transporting atmospheric pressure plasma jet. Antwerp, Belgium, 2015 [22nd Int Symp on Plasma Chemistry].

12 Bender C and Kramer A: Therapy of wound healing disorders in pets with atmospheric pressure plasma. Tierärztl Umschau 71 : 262-268, 2016.

13 Metelmann HR, Vu TT, Do HT, Le TNB, Hoang THA, Phi TTT, Luong TML, Doan VT, Nguyen TTH, Nguyen THM, Nguyen TL, Le DQ, Le TKX, Woedtke T von, Bussiahn R, Weltmann KD, Khalili R and Podmelle F: Scar formation of laser skin lesions after cold atmospheric pressure plasma (CAP) treatment: a clinical long term observation. Clin Plasma Med 1: 30-35, 2013.

14 Matthes R, Assadian O and Kramer A: Repeated applications of cold atmospheric pressure plasma does not induce resistance in Staphylococcus aureus embedded in biofilms. GMS Hyg Infect Control 9: Doc17, 2014.

15 Weiss M, Daeschlein G, Kramer A, Burchardt M, Brucker S, Wallwiener D and Stope MB: Virucide properties of cold atmospheric plasma for future clinical applications. J Med Virol 89: 952-959, 2017.

16 Gümbel D, Gelbrich N, Weiss M, Napp M, Daeschlein G, Sckell A, Ender SA, Kramer A, Burchardt M, Ekkernkamp A and Stope MB: New treatment options for osteosarcoma - inactivation of osteosarcoma cells by cold atmospheric plasma. Anticancer Res 36: 5915-5922, 2016.

17 Bekeschus S, Schmidt A, Bethge L, Masur K, Woedtke T von, Hasse $\mathrm{S}$ and Wende K: Redox stimulation of human THP-1 monocytes in response to cold physical plasma. Oxid Med Cell Longev 2016: 5910695, 2016.

18 Barton A, Wende K, Bundscherer L, Hasse S, Schmidt A, Bekeschus S, Weltmann KD, Lindequist $U$ and Masur $\mathrm{K}$ : Nonthermal plasma increases expression of wound healing related genes in a keratinocyte cell line. Plasma Med 3: 125-136, 2013.

19 Arndt S, Landthaler M, Zimmermann JL, Unger P, Wacker E, Shimizu T, Li Y-F, Morfill GE, Bosserhoff A-K and Karrer S: Effects of cold atmospheric plasma (CAP) on ss-defensins, inflammatory cytokines, and apoptosis-related molecules in keratinocytes in vitro and in vivo. PLoS ONE 10: e0120041, 2015.

20 Gay-Mimbrera J, Garcia MC, Isla-Tejera B, Rodero-Serrano A, Garcia-Nieto AV and Ruano J: Clinical and biological principles of cold atmospheric plasma application in skin cancer. Adv Ther 33: 894-909, 2016. 
21 Garg AD, Nowis D, Golab J, Vandenabeele P, Krysko DV and Agostinis P: Immunogenic cell death, DAMPs and anticancer therapeutics: an emerging amalgamation. Biochim Biophys Acta 1805: 53-71, 2010.

22 Iseki S, Nakamura K, Hayashi M, Tanaka H, Kondo H, Kajiyama H, Kano H, Kikkawa F and Hori M: Selective killing of ovarian cancer cells through induction of apoptosis by nonequilibrium atmospheric pressure plasma. Appl Phys Lett 100: 113702, 2012.

23 Stope MB, Wiegank L, Weiss M, Diesing K, Koensgen D, Burchardt $\mathrm{M}$, Zygmunt $\mathrm{M}$ and Mustea A: Drug-induced modulation of heat shock protein HSPB1 in an ovarian cancer cell model. Anticancer Res 36: 3321-3327, 2016.

24 Stope MB, Delogou S, Diesing K, Klinkmann G, Evert M, Koensgen D, Zygmunt $\mathrm{M}$, Burchardt $\mathrm{M}$ and Mustea $\mathrm{A}$ : Expression pattern of the microRNA miR-1 in ovarian cancer cell lines and tumor tissue samples implies a loss of miR-1's tumor suppressor properties. RNA Dis 1: e348, 2014.

25 Stope MB, Hettenbach D, Kaul A, Paditz M, Diesing K, Burchardt M, Zygmunt M, Mustea A and Koensgen D: The tumor suppressor microRNA-1 exhibits restricted inhibition of proliferation of ovarian cancer cells. Anticancer Res 36: 33293334, 2016.

26 Stope MB, Klinkmann G, Diesing K, Koensgen D, Burchardt M and Mustea A: Heat shock protein HSP27 secretion by ovarian cancer cells is linked to intracellular expression levels, occurs independently of the endoplasmic reticulum pathway and HSP27's phosphorylation status, and is mediated by exosome liberation. Dis Markers 2017: 1575374, 2017.

27 Takamura N, Wang D, Satoh T, Namihira T, Saitoh H and Akiyama $\mathrm{H}$ : Effect of atmospheric-pressure helium plasma jet on cell culture medium. Electronics Communic Jp 97: 65-73, 2014.

28 Bekeschus S, Kolata J, Winterbourn C, Kramer A, Turner R, Weltmann KD, Broker B and Masur K: Hydrogen peroxide: a central player in physical plasma-induced oxidative stress in human blood cells. Free Radical Res 48: 542-549, 2014.
29 Liu DX, Bruggeman P, Iza F, Rong MZ and Kong MG: Global model of low-temperature atmospheric-pressure $\mathrm{He}+\mathrm{H}_{2} \mathrm{O}$ plasmas. Plasma Sources Sci Technol 19: 25018, 2010.

30 Yan D, Cui H, Zhu W, Nourmohammadi N, Milberg J, Zhang LG, Sherman JH and Keidar M: The specific vulnerabilities of cancer cells to the cold atmospheric plasma-stimulated solutions. Scientific Rep 7: 4479, 2017.

31 Baumann WH, Lehmann M, Schwinde A, Ehret R, Brischwein $M$ and Wolf B: Microelectronic sensor system for microphysiological application on living cells. Sensors Actuators B 55: 77-89, 1999.

32 Fridman G, Friedman G, Gutsol A, Shekhter AB, Vasilets VN and Fridman A: Applied plasma medicine. Plasma Process Polymers 5: 503-533, 2008.

33 Kluge S, Bekeschus S, Bender C, Benkhai H, Sckell A, Below $\mathrm{H}$, Stope $\mathrm{MB}$ and Kramer A: Investigating the mutagenicity of a cold argon-plasma jet in an HET-MN model. PLoS ONE 11: e0160667, 2016.

34 Maisch T, Bosserhoff AK, Unger P, Heider J, Shimizu T, Zimmermann JL, Morfill GE, Landthaler $\mathrm{M}$ and Karrer S: Investigation of toxicity and mutagenicity of cold atmospheric argon plasma. Environment Mol Mutagen 58: 172-177, 2017.

35 Shan Y, Guan F, Zhao X, Wang M, Chen Y, Wang Q and Feng $\mathrm{X}$ : Macranthoside $\mathrm{B}$ induces apoptosis and autophagy via reactive oxygen species accumulation in human ovarian cancer A2780 cells. Nutr Cancer 68: 280-289, 2016.

36 Yan D, Cui H, Zhu W, Talbot A, Zhang LG, Sherman JH and Keidar M: The strong cell-based hydrogen peroxide generation triggered by cold atmospheric plasma. Sci Rep 7: 10831, 2017.

Received September 12, 2017

Revised September 26, 2017

Accepted September 27, 2017 